\title{
PENGUJIAN REAKSI PASAR TERHADAP PERISTIWA MERGER DAN AKUISISI DI BURSA EFEK INDONESIA (BEI)
}

\author{
Rintohan Malau ${ }^{1}$ \\ Luh Putu Wiagustini ${ }^{2}$ \\ Luh Gede Sri Artini ${ }^{3}$
}

\author{
${ }^{1,2,3}$ Fakultas Ekonomi dan Bisnis Universitas Udayana (Unud), Bali, Indonesia \\ email: rintohanmalaumm14@gmail.com
}

\begin{abstract}
ABSTRAK
Penelitian ini bertujuan untuk melihat apakah terjadi abnormal return disekitar periode merger dan akuisisi, dengan menggunakanmarket modeldan return harapan 100 hari,serta menggunakan periode peristiwa (event period) yaitu tujuh hari sebelum dan tujuh hari setelah pengumuman merger dan akuisisi. Sampel penelitian ini adalah seluruh perusahaan yang melakukan merger dan akuisisi di Bursa Efek Indonesia selama tahun 2013-2015, pengambilan sampel dalam penelitian ini tidak mempertimbangkan corporate Action lainya selain merger dan akuisisi saja, sehingga diperoleh 30 perusahaan sebagai bahan sampel, alat analisis yang digunakan dalam penelitian ini adalah uji regresi linier berganda dengan Level Of Singnificance sebesar 5\%. Hasil penelitian menunjukkan bahwa tidak terjadi abnormal return disekitar periode penelitian, sehingga dapat dikatakan bahwa tidak ada reaksi pasar disekitar pengumuman merger dan akuisisi yang dibuktikan dengan signifikansi lebih besar dari $0.05 \%$.Kemungkinan besar hal ini terjadi karena tidak ada kebocoran informasi selama kurun waktu penelitian.
\end{abstract}

Kata kunci : abnormal return, merger, akuisisi, average abnormal return, efisiensi pasar

\begin{abstract}
This study aimed to see whether there abnormal returns around the period of mergers and acquisitions, using a market model and the expected returns of 100 days, as well as using the event period is seven days before and seven days after the announcement of mergers and acquisitions. The sample was a company for mergers and acquisitions in Indonesia Stock Exchange during the years 2013-2015, sampling in this study did not consider the corporate Action others besides mergers and acquisitions alone, so it acquired 30 companies as the sample material, the analysis tools used in this research is multiple linear regression with Level of Singnificance by 5\%. The results showed that there were no abnormal returns around the period of the study, so it can be said that there is no market reaction around the announcement of mergers and acquisitions as evidenced by a greater significance than $0.05 \%$. Most likely this is because there is no leakage of information during the period of the study.
\end{abstract}

Keywords : Abnormal Return, Mergers, Acquisitions, Average Abnormal Return, EfficiencyMarket 


\section{PENDAHULUAN}

Pasar yang efisien adalah pasar dimana keseluruhan harga telah tercermin didalamnya sehingga kemungkinan besar bahwa investor tidak akan memperoleh keuntungan dari pasar (Tandelilin, 2010:219). Pasar efisien dengan informasi yang bisa didapat dengan mudah dan diakses dimanapun yang sebenarnya sudah terbentuk harga keseimbangan maka investor tidak akan memperoleh keuntungan tak normal dari suatu informasi yang mereka dapatkan.Bisnis pada saat ini yang semakin berkembang pesat yang tidak hanya di dalam ruang lingkup regional saja tetapi hingga luar negeri memaksa para pelaku bisnis untuk mampu bersaing dengan perusahan yang sejenis dan bahkan yang tidak sejenispun menjadi saingan.Berbagai perjanjian antar Negara memaksa pihak manajemen dalam melakukan suatu tindakan dalam bertahan.

Merger dan Akuisisi merupakan suatu corporate action yang dapat dilakukan oleh pihak manajemen perusahaan guna memperkuat suatu perusahaan bagi segi operasional maupun dalam segi keuangan.Merger dan akusisi dengan tidak langsung dapat mengurangi persaingan bisnis yang sejenis maupun yang tidak sejenis, hal ini dilakukan dalam menghadapi persaingan didalam maupun di luar negeri. Perusahaan akan memperoleh dana talangan serta kewajiban perusahaan yang semakin kecil sebagai keuntungan melakukan kegiatan yang berhubungan dengan suatu Merger dan Akuisisi.

Merger adalah peleburan dua bahkan lebih perusahaan baik yang sejenis maupun tidak sejenis, yang mempunyai kesepakatan dalam membentuk satu perusahaan dengan kesepakatan penggunaaan nama perusahaan yang akan dibuat 
sedangkan Akuisisi pengambilalihan perusahaan secara penuh yang pada akhirnya akan menghilangkan perusahaan yang di Akusisi. Perusahaan yang melakukan merger di Indonesia cenderung didominasi oleh perusahaan yang telah masuk di Bursa Efek.

Disamping faktor laba yang akan diperoleh saat ini, manfaat perusahaan dalam melakukan penggabungan merger dan akuisisi berimbas pada pertumbuhan laba dimasa depan. Pasar modal yaitu bertemunya antara kelebihan dan kekurangan dana(Tandelilin, 2010:26). Lembaga yang menjembatani (intemediaries) adalah salah satu fungsi dari pasar modal itu sendiri, hal ini memberikan peranan yang sangat penting di dalam pasar modal dalam menunjang perekonomian.Bukan hanya itu saja pasar modal dapat menunjang terbentuknya suatu penyaluran dana yang merata karena investor yang mempunyai dana yang berlebih dapat megambil keputusan yang lebih baik atas investasi guna memperoleh return yang optimal.

Study peristiwa dapat dikatakan suatu kegiatan yang melihat reaksi pasar akan adanya suatu informasi yang terkandung dalam suatu pengumuman yang di publikasikan, penelitian ini berusaha dalam pengumuman tersebut apakah terjadi reaksi investor dalam kurun waktu tertentu. Suatu pengumukan merger dan akuisisi dapat dilakuykan sebagai tolak ukur reaksi pasar terhadap suatu informasi yang dipublikasikan oleh pihak yang bersangkutan. Menurut Tandelilin (2010) dalam membuktikan ada tidaknya suatu reaksi pasar dalam suatu pengumuman peristiwa maka perlu adanya pengujian terhadap kandungan suatu informasi, 
sehingga diharapkan ada sebuah reaksi pasar pada saat suatu pengumuman tersebut dapat direspon atau diterima oleh pasar itu sendiri.

Informasi yang diterima oleh pasar atau investor akan ditunjukkan oleh Abnormal Return yang terjadi sehingga ada pihak yang memperoleh keuntungan dari sebuah informasi yang dipublikasikan. Tetapi pandangan atau respon setiap investor terhadap suatu informasi berbeda beda akan menimbukan reaksi yang berbeda juga terhadap reaksi pasar nantinya, tetapi gabungan dari reaksi investor ini akan menunjukkan suatu reaksi pasar yang menghasilkan return. Reaksi pasar dari suatu pengumuman yang dianggab oleh investor mengandung informasi akan memperoleh Abnormal Returnpositif dan sebaliknya jika informasi yang diterima tersebut hal yang biasa saja makan akan menghasilkan abnormal return yang negatif yang tercermin dari perubahan harga sekuritas.

Pada dasarnya tujuan dilakukan penelitian ini untuk melihat signifikansi perbedaan abnornomal return akan sebuah sekuritas perusahaan sebelum adanya pengumuman dari suatu peristiwa dan sesudah pengumuman merger dan akusisi yaitu yaitu kurun waktu tujuh hari penelitian sebelum dan tujuh hari setelah pengumuman merger dan akuisisi.Perbedaan yang terjadi atas hasil penelitian yang dilakukan sebelumnya menuntukkan bahwa masih ada celah untuk meneliti kembali. Beberapa peneliti yang menyimpulkan bahwa ada terjadi perbedaan yang signifikan seperti (Kards, Gordon V et al, 2011) dengan menggunakan study peristiwa berdasarkan CAR dilakukan di AS dan India menyimpulkan ada respon yang terjadi di kedua negara ini setelah dan sebelum merger dan akuisisi, sama halnya juga yang dilakukan oleh (Ma Jianyu et al, 2009) dengan menggunakan 
teori market modelterjadi pengaruh yang positif sebagai akibat dari informasi yang bocor serta adanya perbedaan hasil dari sebuah efek merger dan akuisisi di sektor keuangan dan non keuangan, serta peneliti lainnya seperti (Mirna Dianita et al, 2013), (Nelaam rani \& Surendra S, Kadav, 2013), (Felix Maggnuson \& Andre linberg, 2013) ( Bin Mei dan Changyou Sun, 2009), (Nike Astria, 2009) dan (Epriyeni Ayu dan Rika Kharlina 2013).hasil penelitian meyatakan bahwa adanya respon para investor terhadap pengumuman merger dan akusisi.

Beberapa penelitian yang menolak hasil ini seperti yang diteliti oleh,(Wong, Anson and Kui Yin Cheung. 2009) menyatakan bahwa tidak terjadi adanya abnormal return disekitar periode pengamatan tetapi sebaliknya terjadi CAAR positif di perusahanan pengakuisisi pasca-pengumuman, sama halnya dengan peneliti lainya seperti (Shah, Priyanka dan Parvinder Arora. 2014), (Van Dijk, Leon. 2011), (Liargovas Paragiotis 2011), (Nossi Ariawida 2007). (Kashiramka, Smita \& Muralidhar Rao, 2013), (Ioannis Asimakopoulos, 2008), (Eliya Wahyu Rusnanda, SE. Dan Pardi SE., MM., 2013), (Ida Bagus Gede Dananjaya dan Ni Luh Putu Wiagustini, 2015), (Ikram Faizal, dan Anggoro Budi Nugroho. 2014), dan (vally aquie, 2012). Menemukan bahwa tidak terjadi abnormal return disekitar pengumuman merger dan akuisisi.

Perbedaan hasil serta kesimpulan dari penelitian yang telah dikemukakan sebelumnya sehingga terdapat adanya Gapsehingga memungkinkan untuk perlu adanya penelitian selanjutnya.Marcus (2014) bentuk efisiensi pasar tidak hannya dapat dilihat dari berbagai aspek seperti ketersediaan informasi tetapi bahkan dapat dilihat dari kemampuan dari investor yang berhubungan langsung dengan 
pasar dalam menentukan keputusan berdasarkan analisis informasi yang diperoleh.

Ada 3 efisiensi pasar ditinjau dari bentuk informasinya seperti Efisiensi bentuk lemah (weak form) menjelaskan bahwa harga saham yang telah ada sudah menunjukkan harga sesungguhnya atas informasi yang ada, dimana informasi ini dapat diperoleh dengan cara melihat volume perdagangan atau laporan keuanganya. Yang kedua adalah Efisiensi pasar bentuk setengah kuat menyatakan jika informasi yang dipublikasikan sudah mencerminkan dari keseluruhan informasi yang telah ada, dengan kata lain pasar dalam bentuk setengah kuat keuntungan yang diperoleh oleh investor hanya terjadi dalam kurun waktu yang singkat. Yang terakhir adalah efisiensi pasar bentuk kuat yang menyatakan bahwa seluruh informasi yang ada hanya bagi pihak internal perusahaan saja dan pada dassarnya mempunyai informasi yang privat.

Investor dalam melakukan investasi membutuhkan informasi-informasi yang akurat dalam menentukan keputusan yang tepat dan tepat.Hasil penelitian oleh Alok (2009) menyimpulkan bahwa seorang itu memfokuskan pada posisi penggabungan beberapa saham karena hal ini dapat dipengaruhi oleh tingkat kentungandalam kurun waktu yang cukup panjang.Semua ini investor juga harus mempertimbangkan tingkat risiko atas investasi yang dilakukan, hubungan risiko dengan tingkat pendapatan diinginkan memiliki hubungan yang searah dan linier (Mukherji et al., 2008).

Teori Pesinyalan (Signalling Theory) hal ini menjelaskan bahwa ada suatu signal yang ada dalam suatu peristiwa di dalam suatu pasar. Singnalling 
Theorymempunyai tujuan untuk menarik minat investor dalam berinvestasi dengan menganalisis pengumuman dan informasi yang terkandung didalamnya sehingga dapat memilih informasi yang baik dan informasi yang buruk. Laporan keuangan merupakan suatu bentuk signal suatu informasi yang dapat dipeoleh oleh pihak diluar perusahaan terutama bagi investor guna mengambil suatu tindakan investasi yang tepat dan benar.

Dalam penelitian ini menggunakan studi peristiwa yang dimaksud disini adalah mengamati sebuah peristiwa dari informassi yang muncul atau di publikasikan ke masyarakat sebagai sinyal atas perubahan harga saham jika pihak yang terkait merespon suatu invormasi yang ada.Pembahasan atas suatu studi peristiwa tidak terlepas dari efisiensi pasar bentuk setengah kuat, secara lebih khusus bahwa studi peristiwa untuk mengamati respon atau ketertarikan dari pihak yang terkait terhadap suatu kandungan informasi baik dalam bentuk informasi positif atau informasi negative. Pasar efisien akan terjadi jika investor merespon suatu informasi yang positif dan jakalau suatu informasi yang diterima baik serta untuk respon yang negative jika informasi tersebut merupakan berita buruk.

Return ekspektasi (expected return) dan Return tidak normal (Abnormal return)Expected Return bagian darireturn yang pasti dan harus diperhatikan pada saat melakukan investasi(Hartono Jogiyanto 2010), Expected Return dapat diestimasi dengan menggunakan tiga model yaitu, yang pertama penyesuaian model rata-rata (mean-adjusted model) menganggab akan tingkat pendapatan sama dengan rata-rata return realisasi sebelumnya pada kurun waktu pengamatan. 


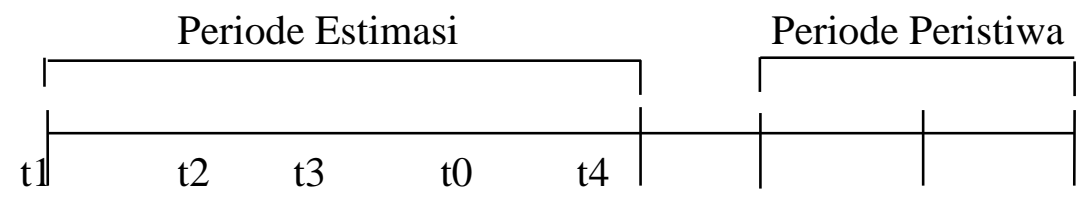

'Sumber: Jogiyanto (2010)

Dimana t1 ke t2 merupakan periode estimasi, t2-t3 merupakan periode pengamatan suatu peristiwa dan t0 merupakan pada saat suatu perusahaan melakukan pengumuman terhadap sautu peristiwa. Model berikutnya adalah Market Model perhitunganya melakukan dua tahapan, yang pertama membentuk model estimasi dan menggunakan model harapan untuk mengestimasi Returndiperiode pengamatan bisa menggunakan regresi OLS dan model yang terakhir adalah Market-Adjusted Model disini tidak menggunakan estimasi tetapi menggunakan return indeks pasar.

Perhitungan yang dilakukan untuk memperoleh return tidak normal dari beberapa saham atau sekuritas yang digunakan sebagai penelitian dalam sebuah peristiwa maka excess return adalah perbedaandari harga suatu saham saat ini dibandingkan dengan harga dari suatu saham yang sama dari sebelumnya atau dengan kata lain kelebihan dari return normal atau bisa juga disimpulkan bahwa return tidak normal merupakan bagian dari selisih antara harga saham sesungguhnya yang terjadi dengan returnexpektasi.Bukan hanya itu saja tetapi dalam penelitian ini juga perlu meghitung rata-rata return tidak normal, dimana dalam hal ini bahwa perhitungnya dilakukan untuk secara agregat bukan tiap-tiap sekuritas secara cross-section untuk tiap-tiap hari pada peristiwa.

Pengujian atas efisiensi pasar bentuk setengah kuat sering menggunakan informasi yang berasal dari suatu corporate action. Menurut Fama, et al., (1969), 
pasar dikatakan efisien jikalau informasi yang diterima oleh investor di pasar dan merespon informasi yang ada sebelum bahkan sesuadah suatu pengumuman peristiwa. Pasar bentuk setengah kuat terjadi apabila tidak ada seorangpun yang mendapatkan keuntungan akan sebuah peristiwa atau tidak terjadi abnormal return.

Bedasarkan uraian diatas seperti latar belakang dan berbagai perbedaan hasil penelitian terdahulu dari pengujian reaksi pasar terhadap peristiwa merger dan akusisi di Bursa Efek Indonesia selama kurun waktu penelitin, maka perlu ada penelitian kembali untuk melihat apakah terjadi abnormal return disekitar periode penelitian serta melihat apakah pasar Indonesia sudah termasuk pasar efisien bentuk setengah kuat atau belum, seperti uraiankerangka konseptual berikut ini pada Gambar 3.1

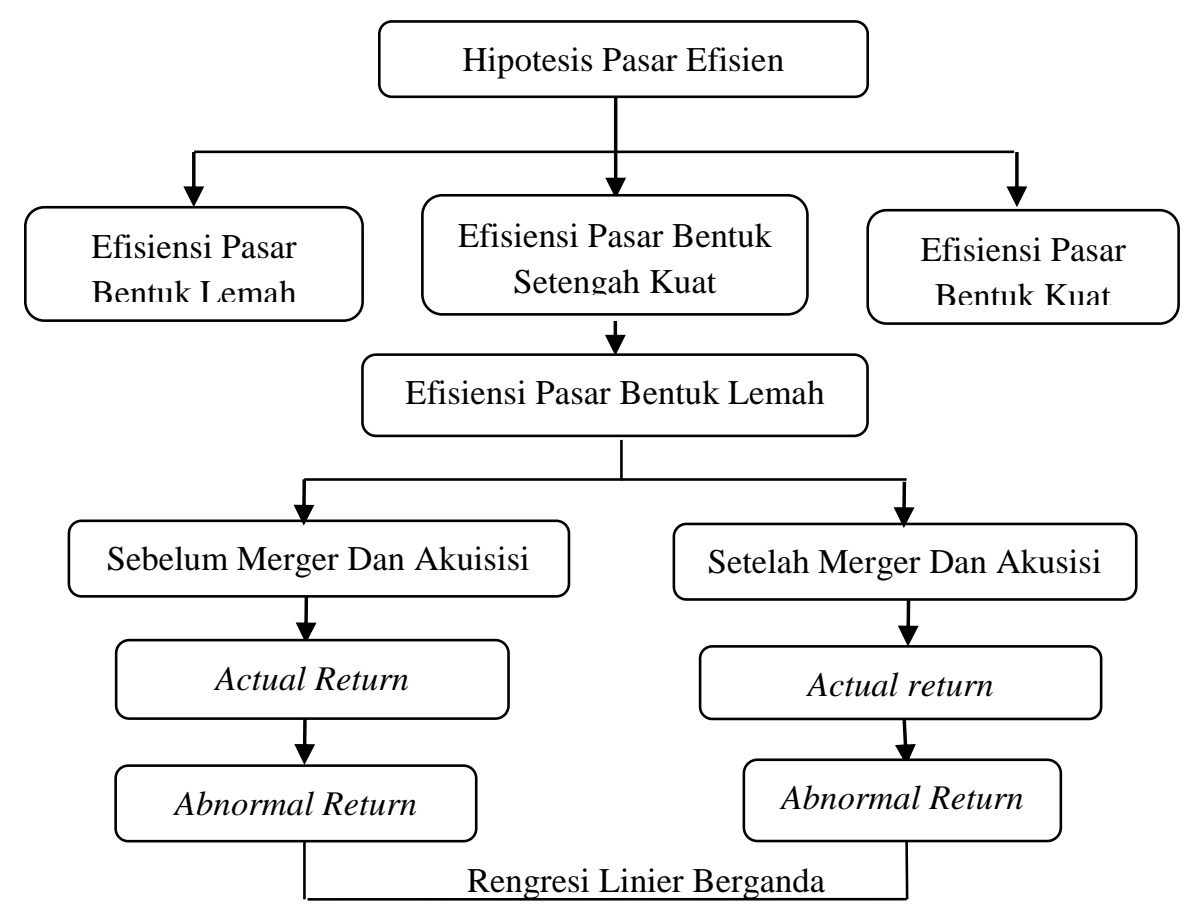

Gambar 3.1 Kerangka Konseptual 


\section{METODE PENELITIAN}

Penelitian merupakan riset conclusive yang bersifat kausal atau bisa juga dikatakan jenis penelitian bentuk metode observasi non pasrtisipan yang dimaksud adalah bahwa peneliti hanya mencatat atau mengamati serta peneliti tidak terlibat didalmnya.Menggunakan analisis regresi linier berganda pada 30 perusahaan sampel.fungsi menggunakann regresi adalah untuk melihat hari keberapa terjadi abnormal returndengan tujuh sebelum dan tujuh setelah pengumuman merger dan akuisisi. Dengan menggunakan variabel terikat (Y) yaitu Average Abnormal Return (AAR), dapat diuraikan berikut ini:

Variable ini memiliki tahapan perhitungan seperti:

a. Menghitung actual return (Jogiyanto Hartono, 2013:207):

$$
R_{i t}=\frac{P_{i t}-P_{i t-1}}{P_{i t-1}}
$$

Dimana: $R_{i t}=$ tingkat keuntungan sesungguhnya saham ipadatahun ke-t

$$
P_{i t}=\text { Nilai saham saat ini }
$$

$P_{i t-1}=$ Nilai saham sebelumnya

b. Perhitungan Return pasar (Jogiyanto Hartono, 2013:207)

$$
\mathrm{R}_{\mathrm{mt}}=\frac{I H S G_{t}-I H S G_{t-1}}{I H S G_{t-1}}
$$

$\mathrm{R}_{\mathrm{mt}}=$ Returntak normal pada saat pengamatan

$\mathrm{IHSG}_{\mathrm{t}}=$ harga saham gabungan pada periode pengamatan

c. Regresikan $R_{i t}$ dengan $R_{m t}$ untuk memperoleh alpha $(\alpha)$ dan beta $(\beta)$.

Dimana formula ini telah dilakukan oleh Mila (2010) dengan rumus:

$$
\beta=\frac{n(\Sigma X Y)-(\Sigma X)(\Sigma Y)}{n\left(\Sigma X^{2}\right)-(\Sigma X)^{2}} \quad \alpha=\frac{\Sigma Y-\beta(\Sigma X)}{n}
$$


$\mathrm{Y}=$ Nilai return saham harian atau $\mathrm{R}_{\mathrm{it}}$

$\mathrm{X}=$ Returnpasar $\left(\mathrm{R}_{\mathrm{mt}}\right)$

$\mathrm{N}=$ Jumalah Pengamatan

d. Perhitungan expected returndalam penggunaan market model, menggunakan dua tahap (Tandelilin,2010:574), atau dapat juga menggunakan teknik regresi OLS.

$\mathrm{R}_{\mathrm{ij}}=\alpha_{\mathrm{i}}+\beta_{\mathrm{i}} \cdot \mathrm{RM}_{\mathrm{j}}+\mathrm{E}_{\mathrm{ij}}$

Dimana:

$\mathrm{R}_{\mathrm{ij}}=$ Returnrealisasisekuritaske-ipadaperiodeestimasike- $\mathrm{j}$.

$\alpha_{\mathrm{i}}=$ Interceptuntuksekuritaske-i.

$\beta_{\mathrm{i}}=$ Koefisienslopeyangmerupakanbetasekuritaske-i.

$\mathrm{RM}_{\mathrm{j}}=$ Returnindekspasarpadaperiodeestimasike- $\mathrm{j}$.

$\mathrm{E}_{\mathrm{ij}}=$ Kesalahanresiduke-ipadaperiodeestimasike-j.

$\mathrm{IHSG}_{\mathrm{t}-1}=$ Indeks Harga Saham Gabungan hari ke- $\mathrm{t}-1$

e. Perhitungan abnormal return untuk setiap saham (Jogiyanto Hartono,

2013:580)

$\mathrm{AR}_{\mathrm{it}}=\mathrm{R}_{\mathrm{it}}-\mathrm{E}_{\mathrm{Rit}}$

Dimana:

$\mathrm{AR}_{\mathrm{jt}}=$ Abnormal Return saham i periode $\mathrm{t}$

$\mathrm{R}_{\mathrm{it}}=$ Actual Returnsaham i periode $\mathrm{t}$

$\mathrm{E}_{\mathrm{Rt}}=$ Expected Returnsaham i periode $\mathrm{t}$

f. Perhitungan untuk Average Abnormal Return (Jogiyanto Hartono,

2013:592)

$\mathrm{AAR}_{i t}=\frac{\sum_{i=1}^{n} A R_{i t}}{n}$

Dimana: ARR :Average Abnormal Return

$\mathrm{n}$ : jumlah dari sampel dan

$\mathrm{AR}$ : average abnormal return 
1. Variable Indepemden $(\mathrm{X})$, atau sering juga disebut variable bebas, penelitian ini yang menjadi variable bebas adalah Abnormal Return (AR), mulai dari AR-7, AR-6, AR-5, AR-4, AR-3, AR-2, AR-1, AR0, AR+1, AR+2, AR+3, $\mathrm{AR}+4, \mathrm{AR}+5, \mathrm{AR}+6, \mathrm{AR}+7$

Return saham peristiwa Merger dan Akusisiadalah perubahanreturnyang terjadi dari setiap harga saham perusahaan selama periode peristiwa Merger dan Akusisi. Periode peristiwa merger dan akusisi yang dimaksudkan adalah selama 15 hari yaitu tujuh hari sebelum pengumuman, saat pengumuman dan tujuh hari sesudah pengumuman merger dan akusisi. Returnsaham dihitung dengan rumus sebagai berikut.

$$
\Delta R_{i t}=\frac{R_{i t}-R_{i t-1}}{P i}
$$

Dimana:

$\Delta R_{i t}=$ Return saham i pada periode peristiwa $\mathrm{t}$

$R_{i t}=$ Return sahami periode $\mathrm{t}$

$R_{i t-1}=$ Return saham i periode $\mathrm{t}-1$

Sumber data diambil dari website www.yahoo-finance.co.id dan Sahamok.com, yaitu perusahaan yang melakukan merger, akuisisi atau keduaduanya selama kurun waktu obsevasi dalam penelitian yaitu pada 2013-2015, jumlah sampel yang digunakan adalah sebanyak 30 perusahaan tetapi proses pengambilan sampel tanpa memperhatikan Corporate Action lainya dengan menggunakan Regresi Linier Berganda.

$$
\begin{aligned}
\mathrm{AAR}_{\mathrm{t}}= & \alpha+\beta_{1} \Delta \mathrm{R}_{-7}+\beta_{2} \Delta \mathrm{R}_{-6}+\beta_{3} \Delta \mathrm{R}_{-5}+\beta_{4} \Delta \mathrm{R}_{-4}+\beta_{5} \Delta \mathrm{R}_{-3}+\beta_{6} \Delta \mathrm{R}_{-2}+\beta_{7} \Delta \mathrm{R}_{-1}+ \\
& \beta_{8} \Delta \mathrm{R} 0+\beta_{9} \Delta \mathrm{R}_{+1}+\beta_{10} \Delta \mathrm{R}_{+2}+\beta_{11} \Delta \mathrm{R}_{+3}+\beta_{12} \Delta \mathrm{R}_{+4}+\beta_{13} \Delta \mathrm{R}+5+\beta_{14} \Delta \mathrm{R}_{+6}+ \\
& \beta_{15} \Delta \mathrm{R}_{+7}+€_{\mathrm{i}}
\end{aligned}
$$


Dimana:

$\mathrm{AAR}_{\mathrm{t}}=$ Rerata abnormal return periode $\mathrm{t}$

$\beta_{\mathrm{t}}=$ Koefisen beta

$€_{\mathrm{i}}=$ Kesalahan acak samadengan nol

$\mathrm{P}=$ Perubahan Return Saham

\section{HASIL DAN PEMBAHASAN}

Dari hasil regresi linier berganda yang diperoleh untuk melihat pengaruh secara langsung dari variabel yang diteliti yaitu abnormal return tiap harinya yaitu selama periode jendela tujuh hari sebelum dan setelah dilakukanya pengumuman merger dan akusisi dapat dipaparkan pada Tabel 5.1

Tabel 5.1 Descriptive Statistics

\begin{tabular}{llrr}
\hline & $\mathrm{N}$ & \multicolumn{1}{c}{ Mean } & \multicolumn{1}{c}{ Std. Deviation } \\
\hline AAR & 30 & .0003 & .00150 \\
AR-7 & 30 & .0032 & .03840 \\
AR-6 & 30 & -.0003 & .03526 \\
AR-5 & 30 & .0019 & .03359 \\
AR-4 & 30 & .0025 & .02965 \\
AR-3 & 30 & -.0129 & .03117 \\
AR-2 & 30 & .0059 & .03546 \\
AR-1 & 30 & .0050 & .03660 \\
AR0 & 30 & -.0092 & .04132 \\
AR+1 & 30 & .0062 & .03326 \\
AR+2 & 30 & -.0057 & .02234 \\
AR+3 & 30 & .0046 & .02730 \\
AR+4 & 30 & -.0021 & .02958 \\
AR+5 & 30 & .0055 & .03302 \\
AR+6 & 30 & .0027 & .03909 \\
AR+7 & 30 & -.0010 & .03926 \\
\hline Valid N (listwise) & 30 & &
\end{tabular}

Sumber: Data Diolah, 2016

Tabel 5.1 menjelaskan bahwa abnormal return yang terjadi ditahun 20132015 pada perusahaan yang melakukan merger dan akuisi di periode jendela hari 
ketujuh sebelum pengumuman merger dan akuisisi (AR-7), jumlah (mean) 0,0032 serta simpangan baku sebesar 0,03840 ini menunjukkan bahwa selama kurun waktu pengamatan, variasi dari AR-7 menyimpang dari nilai rata-rata sebesar 0,03840 .

Abnormal return yang terjadi di periode jendela hari keenam sebelum pengumuman merger dan akuisisi (AR-6), jumlah (mean) sebesar -0,0003 serta simpangan baku 0,03526 ini menunjukkan bahwa selama kurun waktu pengamatan, variasi dari AR-6 menyimpang dari nilai rata-rata sebesar 0,03526.

Abnormal return yang terjadi di periode jendela hari kelima sebelum pengumuman merger dan akuisisi (AR-5),jumlah (mean) sebesar 0,0019 serta simpangan baku 0,03359 ini menunjukkan bahwa selama kurun waktu pengamatan, variasi dari AR-5 menyimpang dari nilai rata-rata sebesar 0,03359.

Abnormal return yang terjadi di periode jendela hari keempat sebelum pengumuman merger dan akuisisi (AR-4),jumlah (mean) sebesar 0,0025 serta simpangan baku 0,02965 ini menunjukkan bahwa selama kurun waktu pengamatan, variasi dari AR-4 menyimpang dari nilai rata-rata sebesar 0,02965.

Abnormal return yang terjadi di periode jendela hari ketiga sebelum pengumuman merger dan akuisisi (AR-3), jumlah (mean) sebesar -0,0129 serta simpangan baku 0,03117 ini menunjukkan bahwa selama kurun waktu pengamatan, variasi dari AR-3 menyimpang dari nilai rata-rata sebesar 00,03117.

Abnormal return yang terjadi di periode jendela hari kedua sebelum pengumuman merger dan akuisisi (AR-2), jumlah (mean) sebesar 0,0059 serta 
simpangan baku 0,03546 ini menunjukkan bahwa selama kurun waktu pengamatan, variasi dari AR-2 menyimpang dari nilai rata-rata sebesar 0,03546.

Abnormal return yang terjadi di periode jendela sehari sebelum pengumuman merger dan akuisisi (AR-1), jumlah (mean) sebesar 0,0050 serta simpangan baku 0,03660 ini menunjukkan bahwa selama kurun waktu pengamatan, variasi dari AR-1 menyimpang dari nilai rata-rata sebesar 0,03660.

Abnormal return yang terjadi di periode jendela pada saat pengumuman merger dan akuisisi (AR0),jumlah (mean) sebesar -0,0092 serta simpangan baku 0,04132 ini menunjukkan bahwa selama kurun waktu pengamatan, variasi dari AR0 menyimpang dari nilai rata-rata sebesar 0,04132 .

Abnormal return yang terjadi di periode jendela sehari setelah pengumuman merger dan akuisisi (AR+1), jumlah (mean) sebesar 0,0062 serta simpangan baku 0,03326 ini menunjukkan bahwa selama kurun waktu pengamatan, variasi dari AR+1 menyimpang dari nilai rata-rata sebesar 0,03326.

Abnormal return yang terjadi di periode jendela hari kedua setelah pengumuman merger dan akuisisi $(\mathrm{AR}+2)$,jumlah (mean) sebesar -0,0057 serta simpangan baku 0,02234 ini menunjukkan bahwa selama kurun waktu pengamatan, variasi dari AR+2 menyimpang dari nilai rata-rata sebesar 0,02234.

Abnormal return yang terjadi di periode jendela hari ketiga setelah pengumuman merger dan akuisisi $(\mathrm{AR}+3)$ jumlah (mean) sebesar 0,0046 serta simpangan baku 0,02730 ini menunjukkan bahwa selama kurun waktu pengamatan, variasi dari AR+3 menyimpang dari nilai rata-rata sebesar 0,02730. 
Abnormal return yang terjadi di periode jendela hari keempat setelah pengumuman merger dan akuisisi (AR+4),jumlah (mean) sebesar -0,0021 serta simpangan baku 0,02958 ini menunjukkan bahwa selama kurun waktu pengamatan, variasi dari AR+4 menyimpang dari nilai rata-rata sebesar 0,02958.

Abnormal return yang terjadi di periode jendela hari kelima setelah pengumuman merger dan akuisisi $(\mathrm{AR}+5)$ jumlah (mean) sebesar 0,0055 serta simpangan baku 0,03302 ini menunjukkan bahwa selama kurun waktu pengamatan, variasi dari AR+5 menyimpang dari nilai rata-rata sebesar 0,03302.

Abnormal return yang terjadi di periode jendela hari keenam setelah pengumuman merger dan akuisisi (AR+6) jumlah (mean) sebesar 0,0027 serta simpangan baku 0,03909 ini menunjukkan bahwa selama kurun waktu pengamatan, variasi dari AR+6 menyimpang dari nilai rata-rata sebesar 0,03909.

Abnormal return yang terjadi di periode jendela hari ketujuh setelah pengumuman merger dan akuisisi $(\mathrm{AR}+7)$,jumlah (mean) sebesar $-0,0010$ serta simpangan baku 0,03926 ini menunjukkan bahwa selama kurun waktu pengamatan, variasi dari AR+7 menyimpang dari nilai rata-rata sebesar 0,03926.

Pengujian asumsi klasik dalam suatu regresi linier berganda harus dilakukan terlebih dahulu, untuk melihat apakah model sudah valid untuk menghindari hasil penelitian yang semu.uji normalitas, uji multikolinieritas dan yang terakhir adalah uji Heteroskedastisitas adalah kriteria tiga hal yang harus dipenuhi dalam uji klasik.

Agar pelitian diaggap layak maka perlu untuk melakukan uji asumsi klasik supaya sesuai dengan kriteria yang dibutuhkan dalam suatu penelitian serta hasil 
penelitian tidak menyimpang, penelitian ini melakukan uji Normalitas, yang tujuanya adalah untuk melihat apakah data yang diolah dengan program sudah terdistribusi dengan normal atau tidak. dari hasil penelitian ini bahwa data terdistribusi normal karena penyebaranya mendekati garis diagonal dapat dilihat dari Gambar 5.1

Normal P-P Plot of Regression Standardized Residual

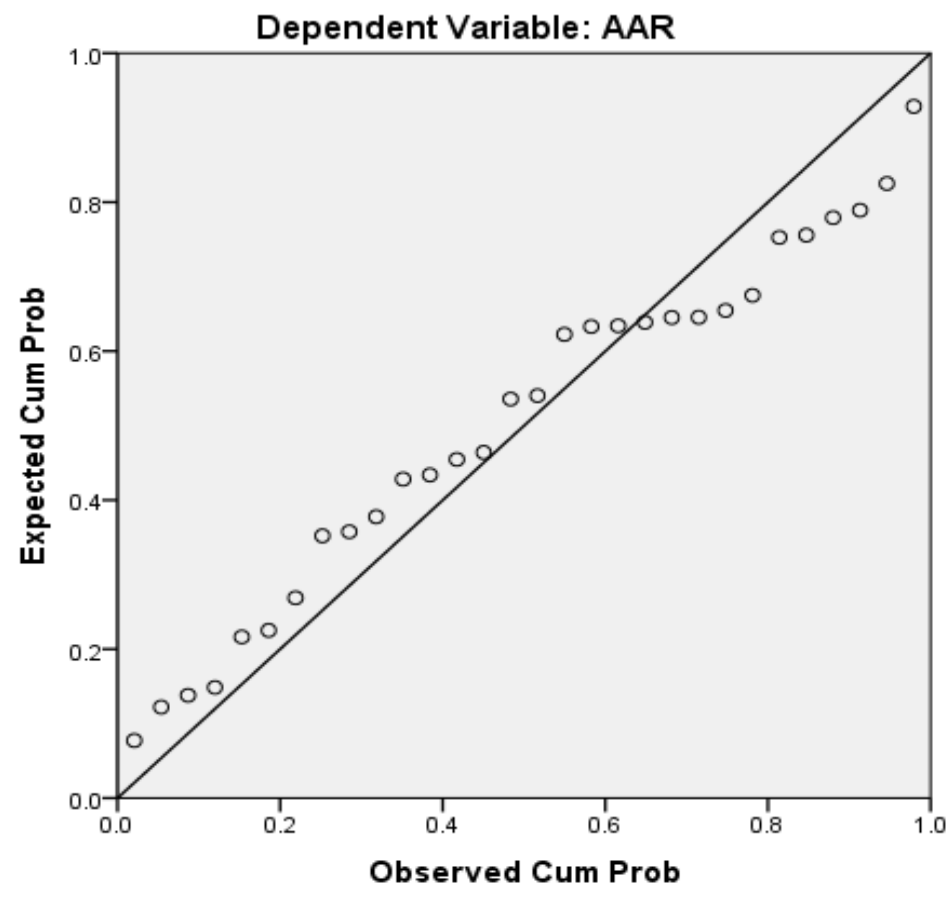

Sumber: data diolah 2016

Suatu model regresi apakah terjadi suatu ketidaksamaan variasi variable dari setiap residual pengamatan maka perlu adanya uji Heteroskedastisitas.Hasil penelitian ini menunjukkan bahwa tidak terjadi heteroskedastisitas, didukung oleh pola titik-titik yang terbentuk pada Gambar 5.2, dalam artian bahwa titik-titk tidak ada dibawah angka nol. 


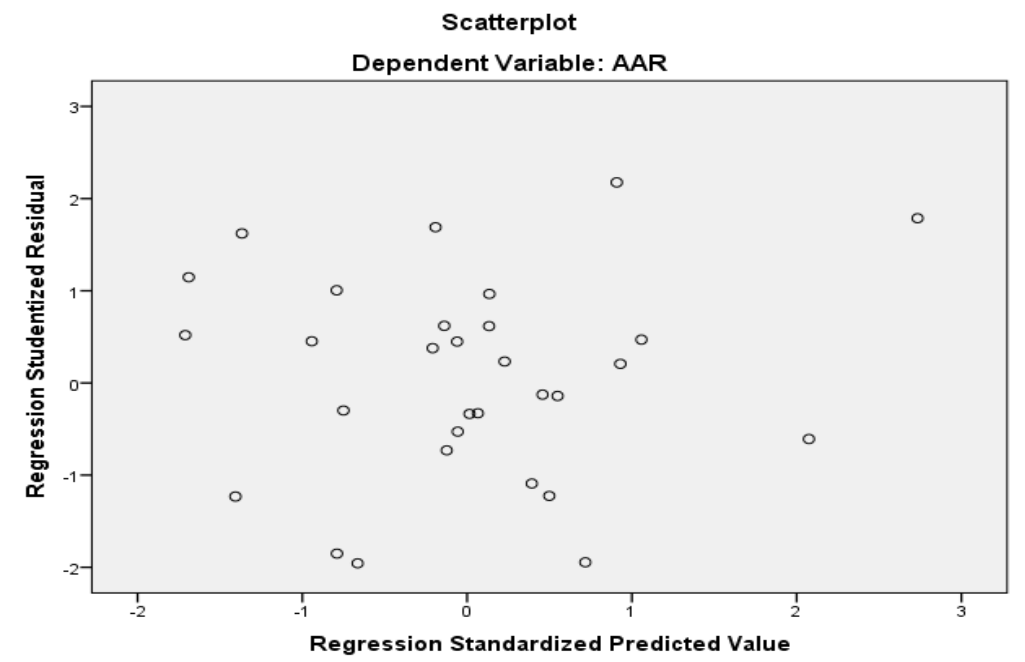

Gambar 5.2

Hasil Uji Heteroskedastisitas Regresi Coefficients ${ }^{\mathrm{a}}$

Sumber: data diolah 2016

Uji Autokorelasi bertujuan untuk melihat apakah ada korelasi antar variable atau pengaruh data pengamatan sebelumnya didalam model regresi yang digunakan.Apabila terjadi Autokorelasi maka dapat disimpulkan bahwa model tersebut tidak baik yang pada akhirnya mendapatkan kesimpulan yang menyimpang.Pengujian yang dilakukan dalam penelitian ini adalah dengan menggunakan Uji Run Tes, Berdasarkan Tabel 5.3 hasil run test menunjukkan bahwa nilai Asymp. Sig. (2-tailed) >0.05, dengan demikian, data dalam penelitian ini sudah cukup random maka tidak terjadi autokorelasi pada data yang dipergunakan, hasilnya dapat ditunjukkn pada Table 5.2

Tabel 5.2

Hasil Uji Autokorelasi Regresi

\begin{tabular}{lr}
\hline \multicolumn{1}{c}{ Model } & $\begin{array}{c}\text { Unstandardized } \\
\text { Residual }\end{array}$ \\
\hline Test Value & -.00011 \\
Cases $<$ Test Value & 15 \\
Cases $>=$ Test Value & 15 \\
Total Cases & 30 \\
Number of Runs & 16 \\
Z & .0000 \\
Asymp. Sig. (2-tailed) & 1.000 \\
\hline
\end{tabular}

a.Median

Sumber: Data Diolah, 2016 
Dalam pembuktian apakah di dalam suatu model penelitian dengan menggunakan regresi linier apakah variabel secara parsial memiliki pengaruh terhadap variabel dependen (AAR) untuk mengetahuainya berikut hasil regresi linier variabel Average Abnormal Return Terhadap Average Abnormal Return pada Tabel 5.3.

Tabel 5.3

Hasil Uji T Sebelum Dan Sesudah Merger Dan Akuisisi

\begin{tabular}{lccccc}
\hline \multicolumn{1}{c}{ Model } & Unstandardized Coefficients & $\begin{array}{c}\text { Standardized } \\
\text { Coefficients }\end{array}$ & T & Sig. \\
& B & Std. Error & Beta & \\
\hline (Constant) & 0.000 & .000 & & 1.291 & .218 \\
AR-7 & .025 & .016 & .016 & 1.530 & .148 \\
AR-6 & .022 & .021 & .021 & 1.067 & .304 \\
AR-5 & .005 & .035 & .035 & .152 & .881 \\
AR-4 & -.010 & .056 & .056 & -.172 & .866 \\
AR-3 & -.029 & .065 & .065 & -.439 & .667 \\
AR-2 & -.032 & .059 & .059 & -.548 & .592 \\
AR-1 & -.011 & .062 & .062 & -.185 & .856 \\
AR0 & .055 & .073 & .073 & .754 & .463 \\
AR+1 & .066 & .081 & .081 & .820 & .426 \\
AR+2 & .066 & .065 & .065 & 1.010 & .330 \\
AR+3 & .045 & .062 & .062 & .715 & .486 \\
AR+4 & .014 & .055 & .055 & .260 & .799 \\
AR+5 &. .021 & .056 & .056 & -.366 & .720 \\
AR+6 & .020 & .032 & .032 & .621 & .545 \\
AR+7 & .015 & .026 & .026 & .597 & .560 \\
\hline Depent & & & &
\end{tabular}

a. Dependent Variable: AAR

Hasil penelitian yang disajikan pada Tabel 5.3, dapat dijelaskan sebagai berikut:

1) pengujian koefisien regresi variabel abnormal returnpada saat hari ketujuh sebelum pengumuman merger dan akuisisi (AR-7)terhadap Average 
Abnormal Return (AAR) pada Tabel 5.3 diperoleh tingkat signifikansi sebesar 0,148 lebih tinggi dari alpa $(\alpha=5 \%)$.

2) Pengujian koefisien regresi variabel abnormal returnpada saat hari keenam sebelum pengumuman merger dan akuisisi (AR-6) terhadap Average Abnormal Return (AAR)tingkat signifikansi sebesar 0,304, lebih besar dari $(\alpha=5 \%)$.

3) Pengujian koefisien regresi variabel abnormal returnpada saat hari kelima sebelum pengumuman merger dan akuisisi (AR-5), terhadap Average Abnormal Return (AAR). Diperoleh tingkat signifikansi sebesar 0,881 lebih tinggi dari $(\alpha=5 \%)$.

4) Koefisien veriabel (AR-4) sebelum pengumuman merger dan akusisiterhadap Average Abnormal Return (AAR).Diperoleh tingkat signifikansi sebesar 0,886 lebih tinggi dari Los (Level of Significance) 0,05 $(\alpha=5 \%)$.

5) koefisien regresi variabel abnormal return hari ketiga sebelum pengumuman merger dan akuisisi (AR-3) Pengaruh abnormal return hari ketiga sebelum pengumuman merger dan akuisisi (AR-3) terhadap Average Abnormal Return (AAR). Diperoleh tingkat signifikansi sebesar 0,667 sedangkan nilai signifikansi lebih tinggi dari $(\alpha=5 \%)$.

6) koefisien regresi variabel abnormal return hari kedua sebelum pengumuman merger dan akuisisi (AR-2) abnormal return hari kedua sebelum pengumuman merger dan akuisisi (AR-2) terhadap Average Abnormal Return (AAR). Diperoleh tingkat signifikansi sebesar 0,592 
sedangkan nilai signifikansi lebih besar dari Los (Level of Significance) $0,05(\alpha=5 \%)$

7) koefisien regresi variabel abnormal return sehari sebelum pengumuman atas merger dan akuisisi (AR-1), abnormal return sehari sebelum pengumuman merger dan akuisisi terhadap Average Abnormal Return (AAR). Diperoleh tingkat signifikansi sebesar 0,856 sedangkan nilai signifikansi lebih besar dari Los (Level of Significance) 0,05 ( $\alpha=5 \%)$.

8) koefisien regresi variabel abnormal returnsetelah pengumuman peristiwaatas merger dan akuisisi (AR0), abnormal return pada saat pengumuman merger dan akuisisi (AR0) terhadap Average Abnormal Return (AAR). Diperoleh tingkat signifikansi sebesar 0,463 sedangkan nilai signifikansi lebih besar dari Los (Level of Significance) $0,05(\alpha=5 \%)$.

9) koefisien regresi variabel $(\mathrm{AR}+1)$ satu hari setelah pengumuman peristiwa atas merger dan akuisisi terhadap Average Abnormal Return (AAR). Diperoleh tingkat signifikansi sebesar 0,426 sedangkan nilai signifikansi lebih besar dari Los (Level of Significance) $0,05(\alpha=5 \%)$.

10) koefisien regresi variabel $(A R+2)$ hari kedua setelah adanya peristiwapengumuman merger dan akuisisi $(\mathrm{AR}+2)$ terhadap Average Abnormal Return (AAR). Diperoleh tingkat signifikansi sebesar 0,330 sedangkan nilai signifikansi lebih besar dari tingkat $(\alpha=5 \%)$.

11) koefisien regresi variabel $(A R+3)$ pada saat hari ketiga setelah merger dan akuisisi $(\mathrm{AR}+3)$, abnormal return hari ketiga setelah pengumuman merger dan akuisisi $(\mathrm{AR}+3)$ terhadap Average Abnormal Return (AAR). 
Diperoleh tingkat signifikansi sebesar 0,486 sedangkan nilai signifikansi lebih besar dari Los (Level of Significance) $0,05(\alpha=5 \%)$.

12) koefisien regresi variabel $(A R+4)$ pada saat hari keempat setelah merger dan akuisisi (AR+4), abnormal return hari keempat setelah pengumuman merger dan akuisisi (AR+4) terhadap Average Abnormal Return(AAR). Diperoleh tingkat signifikansi sebesar 0,799 sedangkan nilai signifikansi lebih besar dari Los (Level of Significance) $0,05(\alpha=5 \%)$.

13) koefisien regresi variabel $(A R+5)$ pada saat hari kelima setelah merger dan akuisisi $(\mathrm{AR}+5)$ abnormal return lima hari setelah pengumuman merger dan akuisisi (AR+5) terhadap Average Abnormal Return (AAR). Diperoleh tingkat signifikansi sebesar 0,720 lebih besar dari nilai alpa 0,05 $(\alpha=5 \%)$

14) koefisien regresi variabel $(A R+6)$ pada saat hari keenam setelah merger dan akuisisi (AR+6), abnormal return hari keenam setelah pengumuman merger dan akuisisi (AR+6) terhadap Average Abnormal Return(AAR). Dengan signifikansi sebesar 0,545 lebih besar dari nilai alpa $0,05(\alpha=5 \%)$.

15) koefisien regresi variabel $(A R+7)$ pada saat hari ketujuh setelah merger dan akuisisi $(\mathrm{AR}+7)$, abnormal return hari ketujuh setelah pengumuman merger dan akuisisi (AR+7) terhadap Average Abnormal Return (AAR). Diperoleh tingkat signifikansi sebesar 0,560 lebih besar dibandingkan dengan nilai alpa $0,05(\alpha=5 \%)$

Sehingga dari hasil penelitian ini dapat diberikan kesimpulan bahwa tidak terjadi abnormal return disekitar periode pengamatan yaitu tujuh hari sebelum 
dan tujuh hari setelah pengumuman merger dan akuisisi, hal ini dibuktikan dengantingkat signifikansi (sig.) $\leq \alpha(0,05)$. Hasil ini juga memaparkan bahwa, tidak terjadi perbedaan yang signifikan sesudah dan sebelum pengumuman merger dan akuisisi di sepanjang periode pengamatan.Hal ini menunjukkan bahwa tidak adanya reaksi pasar di seputar periode pengamatan, serta tidak terjadi kebocoran informasi yang diterima oleh investor sehingga tidak terjadi efisiensi pasar bentuk setengah kuat disekitar pengamatan tujuh hari sebelum dan tujuh hari setelah pada periode penelitian yang dilakukan.

Hasil penelitian ini didukung oleh Bashri, Sajid dan Sheikh (2011) yang menyatakan bahwa peristiwa pengumuman merger dan akuisisi tidak mengandung informasi yang dapat direspon oleh pihak investor. Rusnanda Pardi (2013), mengisyaratkan bahwa bagi pelaku modal atau investor beranggapan bahwa sudah hal yang biasa dan sudah sering menghadapi adanya suatu informasi atau peristiwa merger dan akuisisi, yang berdampak pada harga saham yang tidak berubah atau tidak terjadi Abnormal return.Penelitian ini juga didukung oleh hasil penelitian oleh Asimakopoulus (2008), menyimpulkan bahwa pengumuman merger dan akuisisi dianggap hal yang biasa dan tidak mempunyai pengaruh besar.

Jika dihubungkan dengan signalling theorymengungkapkan bahwa ada suatu peristiwa yang mampu memberikan sinyal informasi dari suatu peristiwa yang berhubungan dengan sinyal yang ada atau informasi yang ada dipasar pada saat itu.Pada saat suatu peristiwa telah terpublikasi kekalangan umum biasanya para pelaku pasar mereview serta memilah informasi yang dianggap 
menguntungkan maupun informasi yang dianggap tidak menguntungkan. Hasil dari observasi penelitian ini para investor merasa sama dengan keadaan sebelum dan sesudah merger dan akuisisi. Pengumuman merger dan akuisisi menyebabkan reaksi pasar yang tercermin pada perolehan adanya hubungan singnifikan antara variabel bebas yaitu abnormal return dengan Average Abnormal Return yang pada intinya menunjukkan apakah pasar Indonesia sudah termasuk pasar efisien atau belum, dari hasil penelitian ini menunjukkan bahwa pasar Indonesia sudah termasuk pasar efisien bentuk setengah kuat.

\section{SIMPULAN DAN SARAN}

Berdasarkan uraian hasil penelitian yang telah dipaparkan diatas makakesimpulan dari penelitian ini dari analisa peristiwa merger dan akuisisi selama 15 hari menunjukkan tidak terjadi signifikan pada kurun waktu pengamatan. Hal ini disebabkan oleh tidak terjadi kebocoran informasi kepada investor, sehingga para investor tidak bereaksi terhadap peristiwa merger dan akuisisi, atau bahkan kebanyakan investor sudah menganggab bahwa peristiwa ini sudah hal yang biasanya yang kemungkinanya tidak akan memperoleh keuntungan yang diharapkan sehingga cenderung mengabaikannya.Dalam penelitinan hasil yang diperoleh tidak ada yang signifikan atau dengan kata lain singnifikansinya lebih besar dari $0,005 \%$ sehingga dapat ditarik kesimpulan bahwa pasar Indonesia sudah termasuk pasar efisien bentuk setengah kuat. Hal ini didukung oleh hasil penelitian yang telah di paparkan sebelumnya, hasil menunjukkan bahwa tidak ada seorangpun yang memperoleh abnormal return 
dari peristiwa merger dan akuisisi selama kurun waktu penelitan yang dilakukan yaitu tahun 2013-2015 di Bursa Efek indonesia (BEI). Untuk dapat memperoleh abnormal return seyogyanya investor perlu mempertimbangkan peristiwa selain merger dan akuisisi, karena informasi merger dan akuisisi tidak menyebabkan investor bereaksi.Untuk penelitian berikutnya disarankan untuk menggunakan metode lain seperti metode CAPM dalam menghitung expected return dan dalam menghitung deviasi standar, untuk mengetahui konsistensi hasil penelitian.Kelemahan penelitian ini adalah dalam pengambilan sampel tidak mempertimbangkan Corporate Action lainya di luar dari Merger dan Akuisisi seperti stock dividend, cash dividend, right issue, bonuss issue, stock split, Initial Public Offering (IPO) dan lainnya. Disarankan juga bagi penelitian selanjutnya agar menggunakan sampel yang lebih besar lagi, dengan kata lain tidak hanya pada periode 3 tahun (yaitu tahun 2013 sampai dengan 2015) namun lebih dari 3 tahun, agar terlihat seberapa besar dampak pengumuman merger dan akuisisi selama yang lebih panjang`periode tersebut. 


\section{REFERENSI}

Aquie, Vally. 2013. Dampak Merger dan Akuisisi terhadap Abnornomal return dan kinerja keuangan bidder firm disekitar tanggal pengumuman Merger dan Akuisisi pada perusahaan yang terdaftar pada bursa efek Indonesia pada tahun 2009-2012. Jurnal mahasiswa Universitas Surabaya, 2 (2): h:1-16

Ariawida, Nossi. 2001, Pengaruh Merger Terhadap Perubahan Harga Saham Dan Net Income Pada Perusahaan Go Public, Tesis.

Asimakopoulos, Ioannis,. Panayiotis P, A. Revisiting the merger and acquisition performance of European banks. h: 1-44.

Astria, Nike. 2009. Analisis dampak pengumuman merger dan akuisisi Terhadap abnornomal returnsaham perusahaan akuisitor Yang terdaftar di bei tahun 2006 - 2008. Jurnal mahasiswa Universitas Brawijaya.

Bodie.Kane. Marcus. 2014. Manajemen Portofolio dan Investasi. Salemba Empat. Jakarta.

Bringham, Eugene, F dan Houston, Joel, F; dialihbahasakan oleh Dodo Suharto dan Herman Widodo, 2001. "Manajemen Keuangan". Jilid II. Penerbit Erlangga. Jakarta.

Capron, Laurance dan Nathalie Priestre. 2002. When Do Acquires Earn Abnormal Returns: Strategic Managements Journal Vol 23 Hal 781-794.

Catranti, Aski. 2009. "Pengaruh Rights Issue Terhadap Imbal Hasil Saham dan Volume Perdagangan”. Jurnal Ilmu Administrasi dan Organisasi.Vol.16, No.3

Charles P.Jones. 2014."Investments Principles and Concepts",John Wiley and Sons Singapore Pte.Ltd, Singapor.

Dananjaya, Ida Bagus Gede dan Ni Luh Putu Wiagustini,. 2015. Studi Komparatif Abnormal Return Sebelum Dan Sesudah Merger Pada Perusahaan Di BEI. E-Jurnal Manajemen Unud, Vol. 4, No. 4, 2015: 1085-1099. ISSN : 2302-8912

Dianita, Mirna., Didi Tarmidi dan Niki Hadian H, 2013. Analysis of Announcement Merger And Acquisition and Payments Method to Stock Return: Study of Listed Companies At Bei During 2005-2011. Procedings of $23^{\text {rd }}$ International Bussiness Research Conference.

Epriyani, Ayu dan Rika Kharlina. 2013. Pengaruh pengumuman merger, akuisisi dan right Issue terhadap abnornomal return saham Di bursa efek Indonesia. JurnalAkuntansi STIE MDP. h: 1-7. Event study Approach. Department of Economics.h: 1-49.

Faizal, Ikram dan Anggoro Budi Nugroho. 2014. Cumulative Average Abnormal Returnand Semistrong Form Efficiency Testing in Indonesian Equity Market Over Restructuring Issue: International Journal of Management and Sustainbility Vol 3 No.9 Hal 552 - 566.

Fama, E., et al. 1969. The Adjustment of Stock Prices to New Informartion.International Economic Review 10: 1-21. 
Hartono, Jogiyanto 2010."Teori Portofolio dan Analisis Investasi”, BPFE Yogyakarta, Edisi Ketujuh, Yogyakarta.

Hartono, Jogiyanto 2013."Teori Portofolio dan Analisis Investasi", BPFE Yogyakarta, Edisi Kedelapan, Yogyakarta.

Kashiramka, Smita,. Rao N,V, Mudhalihar,. 2013. Shareholders wealth effects of Mergers \&Acquisitions in different deal activity periods in India. 5(4): h: $116-129$

Kards, Gordon V dkk. 2011. Cross-Borders Mergers and Acquisitions Between Industrialized and Developing Countries: US and Indian Mergers Activity: International Journal of Banking and Finance Volume 8 Article 3.

Kauffman, Robert J. 2009. Are Online Auction Market Efficient? An Empirical Study Of Market Liquidity and Abnormal Returns. Vol. 48, Iss.1; pg. 3.Decision Suport Systems, Amsterdam.

Kumar Alok, 2009, "Dynamic Style Preferences of Individual Investors and Stock Return, ", Journal of Financial \& Quantitative Analysis

Liargovas, Panagiotis. 2010. The Impact of Mergers and Acquisitions on the Performance of the Greek Banking Sector: An Event study Approach.InternationalJournal of Economics and Finance, 3(2): h: 89-100

Ma Jianyu, Jose A. Pangan and Yun Chu. 2009. Abnormal Return to Mergers and Acquisitions in Ten Asian Stock Markets: International Journal of Bussiness Vol 14 No.3.

Mila, I Gusti Ayu, 2010. Analisis Pengaruh Pemecahan Saham (Stock Split) Terhadap Volume Perdagangan Saham Dan Abnormal Return Saham Pada Perusahaan Yang Terdaftar Di BEI Tahun 2007-2009

Magnusson, Felix and Andre Lindberg, 2013.Payment Method in Mergers and Acquisitions.h:1-26.

Mei, B,. Changyou, S,. Impact of Mergers and Acquisitions on the Forest Products Industry:AndEvent study of Stock Market Returns. h: 1-10.

Mushidzki,TB dan M Ward. 2004. Abnormal Return for Cash VS Share Funded Acquistions: Investments Analysis Journal No.60.

Rani, N,. Yadaf, S, Surendra,.and Jain, K, P,. Impact of Corporate Governance Score on Abnornomal returns of Mergers and Acquisitions.JournalInternational Conference on Apllied Economics, h: 637-646.

Rusnanda,W.E.,Pardi. 2013. Analisa pengaruh pengumuman merger dan akuisisi terhadap abnornomal return saham bank umum di bursa efek Indonesia. Journal Graduasi. 29. ISSN 2088 - 6594. h: 1-101.

Rusnanda, Eliya Wahyu Dan Pardi SE., MM. 2013. Analisa Pengaruh Pengumuman Merger Dan Akuisisi Terhadap Abnormal Return Saham Bank Umum Di Bursa Efek Indonesia. GRADUASI Vol. 29. ISSN $2088-659$

Shah, Priyanka dan Parvinder Arora. 2014. M \&A Announcements and Their Effects on Return to Sharefolders: An Event Study: Accounting and Finance Research Vol 3 No.2. 
Suntoro, denny dan Imam Subekti. 2003. Kandungan Informasi Atas Peristiwa Stock Split: Tema, Volume IV, No 2, September 2003.

Suryanto. 2015. Analysis of Abnormal Return Before and After the Announcements of Investment Grade Indonesia: International Journal of Bussiness and Management Review Vol 3 Hal 11-23.

Telaumbanua,Sumiyana. 2007, Event Study: Pengumuman Laba Terhadap Reaksi Pasar Modal (Study Empiris, Bursa Efek Indonesia 2004-2006) Universitas Gadjah Mada

Tandelilin Eduardus, 2010, "Portofolio dan Investasi", Penerbit Kanisius, Yogyakarta.

Tutut Dewi Astuti dan Di Asih I Maruddani, 2009, Analisis Data Panel Untuk Menguji Pengaruh Risiko Terhadap Return Saham Sektor Farmasi Dengan Least Square Dummy Variable. Media Statistika, Vol. 2, No. 2, Desember 2009: 71-80.

Van Dijk, Leon. 2011. Are There Abnormal Return for The Acquires in Mergers and Acquisitions: An Empirical Study for the United States Financial Sector. period: 07/2005-07/2010

Von Neumann, John, Oskar Morgenstern, (1953) Theory Of Games And Economic Behavior, Princeton: Princeton University Press

Von Gersdoff, Nick. 2009. US Mergers and Acquisitions: A Test of Market Efficiencey: Journal of Finance and Accountancy.

Wong, Anson dan Kui Yin Cheung. 2009. The Effects of Mergers and Acquisition Announcements on the Security Prices of Bidding Firms and Target Firms in Asia: International Journal of Economics and Finance Vol 1 No. 2

No.2
-----------.www.yahoo-finance.co.id
----------.www.sahamok.com

